\title{
Effects of keishibukuryoganryokayokuinin (gui-zhi-fu-ling-wanliao-jia-yiyiren) on the Epidermal Pigment Cells from DBA/2 Mice Exposed to Ultraviolet B (UVB) and/or Progesterone
}

\author{
Hisayoshi Norimoto, ${ }^{*, a}$ Satoshi Yomoda, ${ }^{b}$ Nina Fujita, ${ }^{b}$ Hiromi Tohno-Kosuge, ${ }^{b}$ \\ Seiwa MichinARA, ${ }^{a}$ Masayo KANNARI, ${ }^{a}$ and Toshiki OKUBO ${ }^{a, b}$ \\ Departments of ${ }^{a}$ Pharmacology and ${ }^{b}$ New Product Research, Kampo Research Laboratories, \\ Kracie Pharma, Ltd., Kanebo machi 3-1, Takaoka, Toyama 933-0856, Japan
}

(Received April 8, 2011; Accepted August 10, 2011)

\begin{abstract}
The production of melanin is not only activated by external factors such as sunlight or UV-exposure, but is also considered to be triggered by hormonal factors, particularly sex hormones such as ovarian hormones. Previously, keishibukuryoganryokayokuinin (KBY) was reported to increase the pigmentation and moisture content of dermis in women during the luteal phase of the menstrual cycle, thus suggesting that progesterone could play a critical role in the development of skin pigmentation. In the present study, female DBA $/ 2$ mice, a dilute brown strain, were used to examine the effects of KBY on the increase in epidermal pigment cells in mice exposed to ultraviolet B (UVB) radiation or progesterone in an attempt to elucidate its mechanism. An increase in epidermal pigment cells was observed in mice exposed to progesterone. To the best of our knowledge, this is the first study to demonstrate that progesterone causes pigmentation in vivo. Furthermore, administration of KBY to progesterone-exposed mice significantly reduced the number of epidermal pigment cells. However, KBY had no such effects on UVB-induced pigmentation. Another important finding was the gain in body weight in progesterone-exposed mice, while body weight gain was reduced by KBY. The body weight gain was believed to be due to sodium and fluid retention, a kind of adverse effect of progesterone, which may further affect the intracellular $\mathrm{pH}$ of melanosomes, which synthesize melanin, in turn, leading to melanin production because tyrosinase activity is linked to the intracellular $\mathrm{pH}$ environment. This may help explain the mechanism of the role of KBY in pigmentation.
\end{abstract}

Key words—-keishibukuryoganryokayokuinin; DBA/2 mouse; ultraviolet B (UVB); epidermal dopa-positive cell; progesterone

\section{INTRODUCTION}

Melanin pigment is produced normally by melanocytes when skin is exposed to ultraviolet (UV) radiation of sunlight, and plays an important defensive role against the harmful effects of UV. On the other hand, excessive melanin deposition has a cosmetic impact for many women, causing emotional and psychosocial distress. ${ }^{1}$

Hyperpigmentation is sometimes seen during pregnancy and this condition is called melasma (chloasma or the mask of pregnancy) which occurs mainly on sun-exposed areas of the face. ${ }^{2)}$ It usually fades or disappears soon after parturition, suggesting that sex hormones may affect the production of pigmentation. Melasma has been assumed to be due to the increased output of ovarian hormones because it also occurs when women take oral contraceptives containing

\footnotetext{
*e-mail: h_norimoto@phm.kracie.co.jp
}

derivatives of progesterone and estrogen, or receive estrogen replacement therapy. ${ }^{3)}$ Moreover, earlier studies have shown a similar form of facial hyperpigmentation which waxes and wanes with each menstrual cycle, and the skin of women is more sensitive to ultraviolet light and is more vascular during the premenstrual phase of the menstrual cycle. ${ }^{4,5)}$ In clinical practice, although there are many treatments (e.g., bleaching or skin agents lightening, chemical peels and laser) available, the treatment of hyperpigmentation is often unsuccessful and is still a challenge for dermatologists.

Previously, we found by means of a sample questionnaire and a facial pigment analytical apparatus that keishibukuryoganryokayokuinin (KBY), a Kampo (Chinese herbal medicine) formulation, increases the pigmentation and water content of dermis in women during the luteal phase of the menstrual cycle. ${ }^{6,7)} \mathrm{KBY}$ is a Japanese folk formula stemming from the traditional Chinese formula gui-zhi-fu-ling- 
wan (keishibukuryogan in Japanese) by adding the herbal medicine Coix semen (Yokuinin), 8) while Guizhifulingwan consists of Cinnamomum and Moutan cortex, Paeoniae radix, Hoelen, and Persicae semen. Sato et al. reported that high progesterone levels in the serum are associated with an increase in skin pigmentation during the luteal phase of the menstrual cycle in Japanese female subjects with melasma. ${ }^{9)}$ Moreover, it has been observed that postmenopausal women who are given progesterone develop melasma, while those who are given only estrogen do not. ${ }^{10)}$ These facts implicate progesterone as playing a critical role in the development of skin pigmentation in women.

In the present study, female DBA/ 2 mice, ${ }^{11)}$ a dilute brown strain, were used to examine the effects of $\mathrm{KBY}$ on the increase in epidermal pigment cells from mice exposed to ultraviolet B (UVB) radiation and/ or progesterone in an attempt to elucidate its mechanism.

\section{MATERIALS AND METHODS}

Animals Female DBA/2 mice (5 weeks old, 16 $-21 \mathrm{~g}$ on arrival) were purchased from SLC, Inc., Shizuoka, Japan. They were reared in an air-conditioned animal house facility (room temperature 23 $\pm 2^{\circ} \mathrm{C}$; reversed 12-h light/dark cycle; relative humidity $55 \pm 10 \%$ ) at the Kampo Research Laboratories of Kracie Pharma, Ltd. The mice were housed in sterilized polypropylene cages (6 mice/cage) and provided laboratory pellet chow (CE-2, Clea Japan, Inc.) and water ad libitum. Before experimental procedures, they were acclimatized to the room for one week. This protocol was reviewed and approved by the Experimental Animal Care Committee of Kracie Pharma, Ltd.

Chemicals and UV Radiation The dried extract powder of keishibukuryoganryokayokuinin (Lot No. LKBYE 14E-T, Kracie Pharma, Ltd.) was used in the present study. The extract powder was suspended in $0.5 \%$ sodium carboxymethyl cellulose (CMC-Na) just before use and administered orally at a dose of 0.18 and $1.8 \mathrm{~g} / \mathrm{kg}$ body weight/day based on the daily clinical dose $(1800 \mathrm{mg} /$ day). Progesterone (Lot No. ASL1401) was purchased from Wako Pure Chemical Industries, Ltd., Japan.

In the UV radiation experiment, the mice were exposed to ultraviolet-B (UVB, 290 320 nm) lamps (TOREX FL20S-E-30/DMR, Toshiba Medical Supply, Japan) at a fluorescence of $0.3 \mu \mathrm{J} / \mathrm{cm}^{2} / \mathrm{s}$. Intensity of the radiation was measured with a UV light meter (Model UV-340, Custom Inc., Japan).

Treatment of DBA/2 Mice Exposed to UV Radiation or Progesterone with KBY 1 1) In the UV radiation experiment, DBA $/ 2$ mice were randomly assigned to a normal group, control group, or one of two KBY experimental groups. There were 6 animals in each group. All except the normal mice were exposed to radiation for $5 \mathrm{~min}\left(0.09 \mathrm{~J} / \mathrm{cm}^{2}\right)$ per day for 10 days according to Fig. 1A. After $1 \mathrm{~h}$ of UVB radiation, normal and control mice were treated the same as the experiment group but were orally administered $0.5 \%$ CMC-Na solution daily. The mice in the experimental groups were orally administered the KBY extract at a dose of 0.18 and $1.8 \mathrm{~g} / \mathrm{kg}$, respectively.

2) In the progesterone-exposure experiment, progesterone was diluted in corn oil and administered intraperitoneally at a dose of $1 \mathrm{mg} / 0.2 \mathrm{ml} /$ mouse/ day. ${ }^{12)}$ The group assignment and experimental schedule were the same as described in the UVB radiation experiment above. Briefly, 24 mice were randomly divided into 4 groups $(n=6)$, and all groups were treated with a consecutive intraperitoneal administration of progesterone, with the exception of the normal mice that were treated with corn oil only (Fig. 1B). One hour later, all animals were given $0.5 \%$ CMC-Na solution or KBY extract like in the UVB radiation experiment.

B)

Corn oil or progesterone (1 mg/0.2 ml/mouse/day, i.p.)

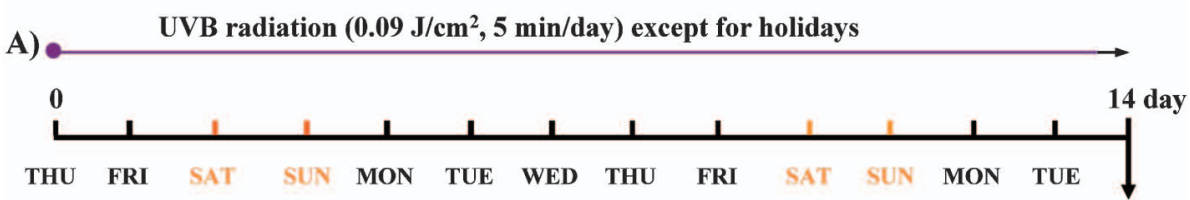

Fig. 1. Experimental Schedule for UVB Radiation (A) and Progesterone Exposure (B) 
Tissue Preparation and Staining In both the UVB radiation and progesterone exposure experiments, the ears were surgically excised from the mice after sacrifice by ether euthanasia. The epidermis was obtained and stained by the dopa-staining technique, which has been described in detail previously. ${ }^{11)}$

Briefly, the ear was cut into $6 \mathrm{~mm}$ sections with a biopsy punch $(\phi 6.0 \mathrm{~mm}$, Kai Industries Co., Ltd., Japan) and mechanically spilt into dorsal and ventral halves. The dorsal surface was incubated at $37^{\circ} \mathrm{C}$ for 2 $h$ in $2 \mathrm{~N} \mathrm{NaBr}$ solution, and then washed with $0.1 \mathrm{M}$ phosphate buffer solution ( $\mathrm{pH}$ 7.2) several times and kept in the solution for one night. The following day, the epidermis was peeled away from the dermis and incubated at $37^{\circ} \mathrm{C}$ for $6 \mathrm{~h}$ in a freshly prepared solution of buffered $0.1 \%$ dopa ( $d l-3$, 4-dihydroxyphenylalanine, Sigma Chemical Company).

The tissue was dehydrated with glycerol (for fluorescence microscopy, Merck, Germany) and mounted on a microscope slide and then covered with a cover slip for viewing through an optical microscope (BX50F4, Olympus Co., Ltd, Japan). An ocular grid was inserted into the eyepiece. The number of dopapositive dendritic cells per $0.24 \mathrm{~mm}^{2}$ in 5 standardized sites in each ear was counted, and their means from two ears were used in this study.

Measurements of Progesterone, Luteinizing Hormone (LH), Follicle Stimulating Hormone (FSH) and Luteinizing Hormone-releasing Hormone (LHRH) in Serum of Mice At the end of an experiment, blood from each animal was collected by decapitation in diethyl ether anesthesia and allowed to clot at room temperature for $1 \mathrm{~h}$. Serum samples were prepared by centrifugation at $10000 \mathrm{rpm}$ for 10 min and stored at $-20^{\circ} \mathrm{C}$ until assay. Serum levels of progesterone (Lot No. 00441, Neogen ${ }^{\circledR}$ Corporation, USA), luteinizing hormone (Lot No. 042404, Endocrine Technologies, Inc., USA) and follicle stimulating hormone (Lot No. 091404, Endocrine Technologies, Inc., USA), and luteinizing hormone-releasing hormone (Lot No. 019114, Peninsula Laboratories, Inc., USA) were measured with ELISA test kits. These ELISA kits were purchased from Junsei Chemical and Cosmo Bio Co., Ltd., Japan. All of the samples were run at the same time to avoid inter-assay variation.

Statistical Analysis The experimental data are expressed as mean \pm S.E.M. Statistical significance was evaluated by a one-way analysis of variance (ANOVA) followed by Dunnett's test for multiple comparisons. Values of $p$ less than 0.05 were accepted as statistically significant.

\section{RESULTS}

KBY Had No Effect on the Number of Epidermal Dopa-positive Cells from DBA/2 Mice Induced by UVB DBA $/ 2$ mice exposed to UVB radiation resulted in a significant increase in the number of dopa-positive cells in the pinnal epidermis from DBA $/ 2$ mice when compared with the normal group mice (Figs 2 and 3). Following administration of KBY $(0.18$ and $1.8 \mathrm{~g} / \mathrm{kg}$, p.o. $)$ to the $\mathrm{DBA} / 2$ mice exposed to UVB radiation for 13 days (Fig. 3), the number of dopa-positive cells was not significantly different in the experimental groups compared with those in the control group.

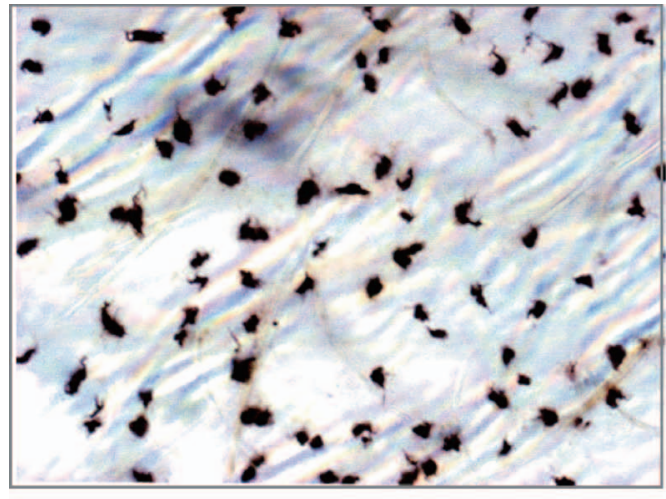

A

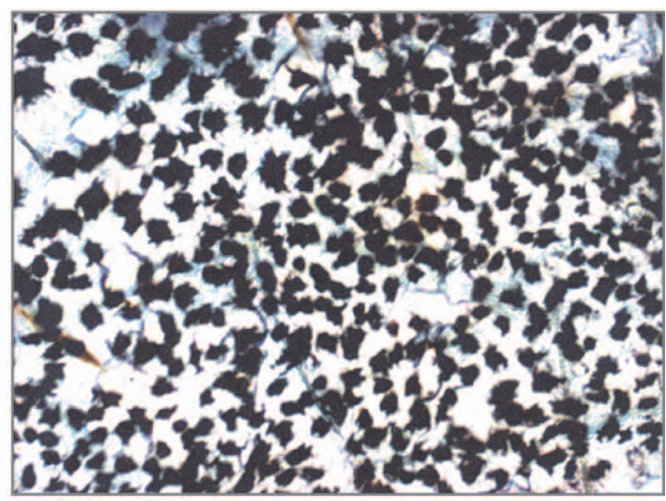

B

Fig. 2. Optical Micrograph of Two Sheets of Pinnal Epidermis from DBA/2 Mouse A: Normal; B: UVB radiation. Magnification $(10 \times 10)$. 
Effect of KBY on the Number of Epidermal Dopapositive Cells from DBA/2 Mice Exposed to Progesterone

Changes in Body Weight during Experiments

Figure 4A shows the changes in body weight of DBA/ 2 mice treated with progesterone exposure during with or without administration KBY. Body weight was significantly increased on day 5 and thereafter was at a higher level in the control group compared with that in the normal group. However, administration of KBY to mice exposed to exogenous progesterone resulted in a decrease in body weight, particularly in the group given a high dose of KBY, to normal levels although the decrease was not significant (Fig.

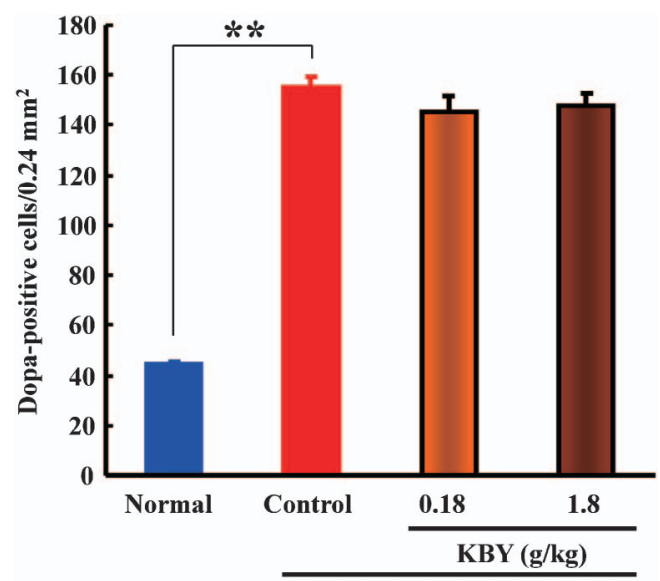

UVB-radiation

Fig. 3. Effect of KBY on the Numbers of Epidermal Dopapositive Cells from UVB-exposed DBA/ 2 Mice Means \pm S.E.M., $n=6,{ }^{* *} p<0.01$.

A)

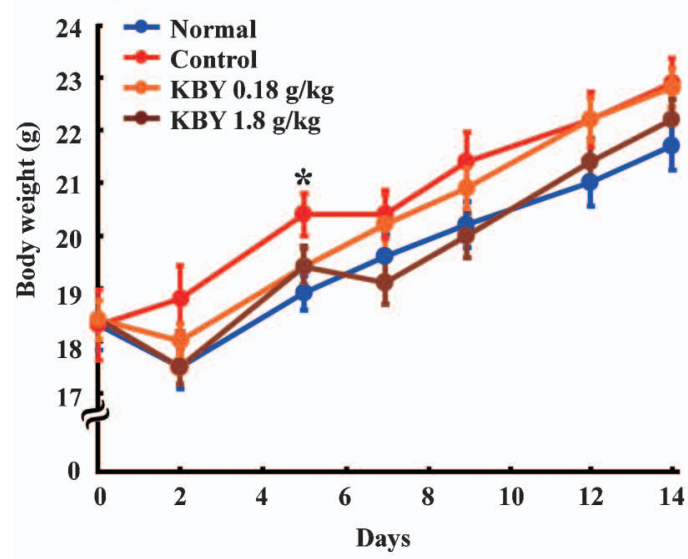

4B).

Treatment of DBA/2 Mice Exposed to Progesterone with KBY Earlier studies have implied that ovarian hormones could give rise to hyperpigmentation, however, studies in vitro concerning the effects of progesterone on human melanocytes have led to inconsistent data. ${ }^{13,14)}$ In order to examine the effect of progesterone on the number of pigment cells, exogenous progesterone $(1 \mathrm{mg} / 0.2 \mathrm{ml} / \mathrm{mouse} /$ day, i.p.) was given to DBA/ 2 mice for 13 days. As shown in Fig. 5, administration of exogenous progesterone resulted in a significant increase in the number of dopa-positive cells in the pinnal epidermis when compared with the normal group. However, the number

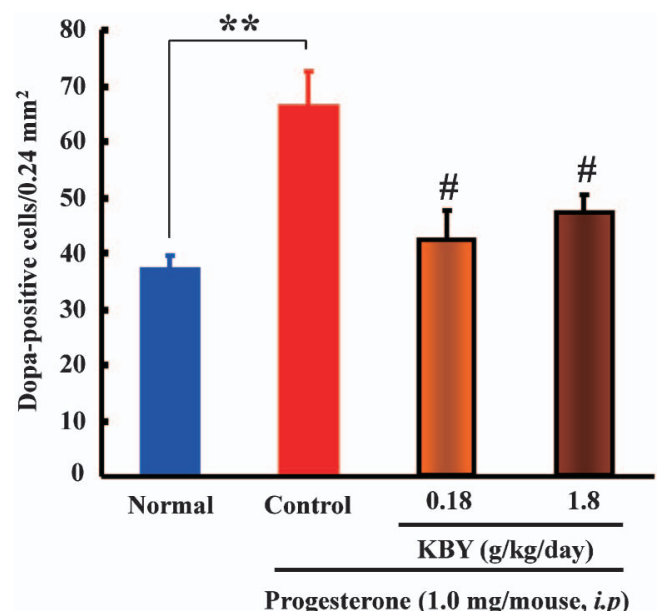

Fig. 5. Effect of KBY on the Numbers of Epidermal Dopapositive Cells from Progesterone-exposed DBA/2 Mice Means \pm S.E.M., $n=6,{ }^{* *} p<0.01$ vs. normal; ${ }^{*} p<0.05$ vs. control.

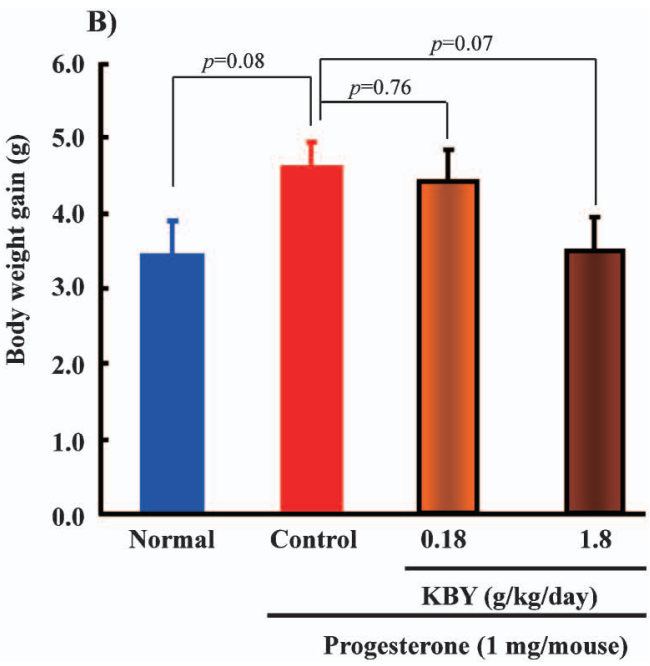

Fig. 4. Changes of Body Weight during Administration of KBY in DBA/2 Mice Exposed to Progesterone Means \pm S.E.M., $n=6$. 
Table 1. Serum Progesterone, LH, FSH and LH-RH Levels in Mice

\begin{tabular}{lcccc}
\hline \hline & Normal & Control & KBY-0.18 & KBY-1.8 \\
\hline Progesterone $(\mathrm{ng} / \mathrm{ml})$ & $1.5 \pm 0.77$ & $4.0 \pm 0.67$ & $3.4 \pm 0.73$ & $3.8 \pm 0.94$ \\
LH-RH $(\mathrm{pg} / \mathrm{ml})$ & $154 \pm 18.5$ & $175 \pm 18.9$ & $176 \pm 19.9$ & $178 \pm 21.4$ \\
LH $(\mathrm{ng} / \mathrm{ml})$ & $0.33 \pm 0.08$ & $0.45 \pm 0.09$ & $0.34 \pm 0.05$ & $0.18 \pm 0.06$ \\
FSH $(\mathrm{ng} / \mathrm{ml})$ & $0.563 \pm 0.004$ & $0.565 \pm 0.004$ & $0.555 \pm 0.004$ & $0.555 \pm 0.004$ \\
\hline
\end{tabular}

LH-RH: luteinizing hormone-releasing hormone; LH: luteinizing hormone; FSH: follicle-stimulating hormone.

of dopa-positive cells induced by progesterone was significantly decreased in the experimental groups treated with KBY at a dose of 0.18 and $1.8 \mathrm{~g} / \mathrm{kg}$.

\section{Serum Progesterone, LH, FSH and LH-RH Levels}

In addition to the LH-RH level, the serum levels of pituitary hormones ( $\mathrm{LH}$ and FSH) and progesterone of the mice exposed to exogenous progesterone in all groups are tabulated in Table 1. Although exogenous progesterone gave rise to an elevation of serum progesterone, the serum LH-RH, LH and FSH levels were not significantly altered. Moreover, KBY did not alter the elevated progesterone levels or the serum levels of LH-RH, LH and FSH of the mice exposed to exogenous progesterone.

\section{DISCUSSION}

Melanocytes are well known for their role in skin pigmentation through the production of melanin. The production of melanin is not only activated by external factors such as sunlight or UV-exposure, but is also triggered by hormonal factors, particularly ovarian hormones such as estrogen and progesterone. Previous studies have reported that a Kampo formula, keishibukuryoganryokayokuinin (KBY), could improve facial pigmentation and water content during the luteal phase of the menstrual cycle in women. ${ }^{6,7)}$

In the present study, KBY did not suppress an increase in the number of epidermal pigment cells induced by UVB radiation in DBA $/ 2$ mice. The epidermis is frequently exposed to solar UV radiation, in particularly its UVB $(290 \sim 320 \mathrm{~nm})$ component, which causes the generation of free radicals and relevant reactive oxygen species, as well as the secretion of cytokines and inflammatory mediators, which leads to develop dendritic melanocytes and show a higher degree of melanization. ${ }^{15-17)}$ It has been reported that KBY or its ingredients such as Cinnamomum and Moutan cortex, and Paeoniae radix show radical scavenging activities, ${ }^{18,19)}$ however, these activities do not appear to help improve the pigmentation induced by UVB radiation.

On the other hand, sex hormones have been recognized as a critical inducer in the production of pigmentation and human melanocytes are responsive to a multiplicity of hormone triggers, particularly to pituitary or ovarian hormones. ${ }^{20,21)}$ Studies concerning the effects of progesterone on human melanocytes, however, have led to inconsistent data. ${ }^{13,14)}$ In order to examine the effect of progesterone on the number of pigment cells, the mice were further subjected to exogenous progesterone exposure, which resulted in a significant increase in the number of epidermal pigment cells in the DBA $/ 2$ mice. This result supported the clinical observations that progesterone plays a crucial role in the development of pigmentation. To the best of our knowledge, the present study is the first to confirm that progesterone causes an increase of pigment cells in vivo.

Furthermore, administration of KBY to progesterone-exposed mice resulted in a significant decrease in the number of pigment cells compared to control. Melanin biosynthesis takes place in melanosomes, which are lysosome-like organelles within the melanocytes, where melanin granules are synthesized using the amino acid tyrosine as the substrate (Fig. 6).22) Within melanosomes, at least three melanocytespecific enzymes, namely, tyrosinase and tyrosinaserelated proteins 1 and 2 (TRP-1 and TRP-2), are further involved in this enzymatic process that converts tyrosine to melanin pigments.

Figure 6 also shows a progesterone pathway (pathway-1) involved in the production of melanin on the basis of the two following reports. Maeda et al. ${ }^{20)}$ reported that the human melanocyte response to pituitary hormones and ovarian hormones is different. Specifically, pituitary hormones ( $\mathrm{LH}$ and FSH) increase both tyrosinase activity and TRP-1, while ovarian hormones (estradiol and progesterone) increase TRP-1 but not tyrosinase activity. In contrast, 


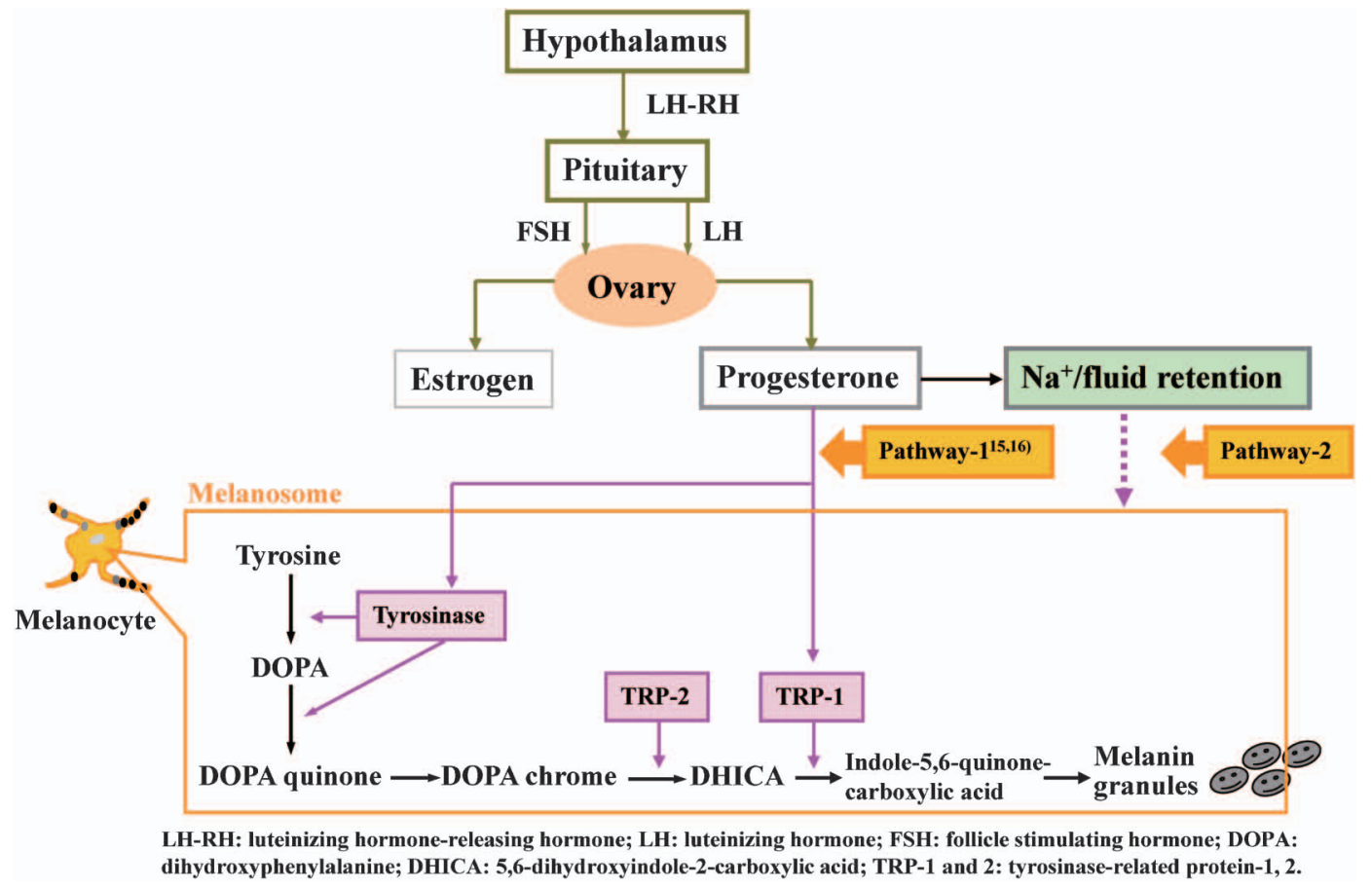

Fig. 6. Process of Melanogenesis within Epidermal Melanosomes and a Proposed Pathway of KBY against Pigmentation

Im et al. ${ }^{21)}$ reported that progesterone increased the number of melanocytes and tyrosinase activity in melanocytes from three of eight donors.

In the examination of serum levels of pituitary and ovarian hormones in all groups after this experiment (Table 1), we found that KBY did not alter the serum levels of these hormones, although exogenous progesterone gave rise to higher levels of serum progesterone. In addition, there were no significant changes in the uppermost stream hormone LH-RH level. These results suggest that KBY may act directly on melanogenesis, and not by intercepting feedback regulating serum progesterone via the hypothalamus-pituitaryovary axis. Sakamoto et al. ${ }^{23)}$ reported that gui-zhifu-ling-wan (keishibukuryogan), a formula that is similar to KBY without the ingredient Yokuinin, acts as a LH-RH antagonist and/or anti-estrogen to regulate pituitary and/or ovarian hormone levels.

In addition, KBY did not show estrogen-like or anti-estrogen activities in an MCF-7 cell proliferation test (data not shown). MCF-7 cells are a breast cancer cell line that is a useful in vitro model system to study responses to sex hormones.

Progesterone is designated as "the hormone of pregnancy" and plays a key role in almost all species, but also has well-known adverse effects, such as increasing sodium and fluid retention, and psychologi- cal effects (e.g., mood swings, fatigue). ${ }^{24)}$ In this study, it is worth noting that the body weight of DBA $/ 2$ mice increased during progesterone administration (Fig. 2). On the contrary, KBY suppressed body weight gain in progesterone-exposed mice. These results provide important information to help explain how KBY decreases the number of epidermal pigment cells in progesterone-exposed mice. In other words, the results seem to imply the possibility of a link between body weight gain or loss and an increase or decrease in pigment cells.

Administration of exogenous progesterone to mice may lead to sodium and fluid retention, thereby increasing body weight gain. Recent studies have implicated low melanosome-associated tyrosinase activity in white melanocytes in association with an acidic $\mathrm{pH}$ environment within the melanosome, and sodium/ hydrogen $\left(\mathrm{Na}^{+} / \mathrm{H}^{+}\right)$exchangers (NHEs) are known to regulate intracellular $\mathrm{pH} .{ }^{25}$ ) Hence, it could be hypothesized that the adverse effect of progesterone on increasing sodium and fluid retention may bring about high intracellular $\mathrm{pH}$, which in turn may augment the tyrosinase activity, leading to the development of melanogenesis. KBY, as shown in proposed pathway-2 (Fig. 6), may decrease the production of melanin pigment by improving sodium and fluid retention induced by progesterone. Meanwhile, this 
makes it of interest to examine the effect of KBY on sodium/hydrogen exchangers.

A limitation of this study is that the estrous cycle of the mice was not taken into account in the administration of progesterone and/or KBY treatment experiment, which may have affected the changes in serum hormones.

\section{REFERENCES}

1) Balkrishnan R., McMichael A., Camacho F., Saltzberg F., Housman T., Grummer S., Feldman S., Chren M., Br. J. Dermatol., 149, 572-577 (2003).

2) Toung Kang H., Ortonne J., Melasma Update, Actas Dermosfiliorg., 100 (suppl.), 110113 (2009).

3) Jelinek J., Arch. Dermatol., 101, 181-186 (1970)

4) McGuinness B., Br. Med. J., 26, 563-565 (1961).

5) Snell R., Turner R., J. Invest. Dermatol., 47, 147-155 (1966).

6) Fujita N., Kosuge H., Yomoda S., Abstract of papers, the 128th Annual Meeting of Pharmaceutical Society of Japan, Yokohama, March 2008, No. 3, p. 146.

7) Kosuge H., Fujita N., Yomoda S., Abstract of papers, the 128th Annual Meeting of Pharmaceutical Society of Japan, Yokohama, March 2008, No. 3, p. 146.

8) "The Guidebook of Non-prescription Kampo Formulae," ed. by The Ministry of Health and Welfare, Yakugyo-jihosha Press, Tokyo, 1975, pp. 75-76.

9) Sato N., Jpn J. Dermatol., 97, 937-943 (1987)

10) Bolanca I., Bolanca Z., Kuna K., Vukovié A.,
Tuckar N., Herman R., Grubisié G., Coll. Antropol., 32 (Suppl.), 139-141 (2008).

11) Nordlund J., Collins C., Rheins L., J. Invest. Dermatol., 86, 433-437 (1986).

12) Pakrashi A., Bhattacharya K., Kabir S., Pal A., Contraception, 34, 523-536 (1986).

13) Hall A., Krishnamoorthy L., Orlow S., Pigment Cell Res., 16, 149-158 (2003).

14) Wiedemann C., Nägele U., Schramm G., Berking C., Contraception, 80, 292-298 (2009) .

15) Friedmann P., Gilchrest B., J. Cell. Physiol., 133, 88-94 (1987).

16) Krutmann J., J. Derm. Sci., 23, S22-S26 (2000)

17) Fisher G., Kang S., Varani J., Bata-Csorgo Z., Wan Y., Datta S., Voorhees J., Arch. Dermatol., 138, 1462-1470 (2002).

18) Sekiya N., Goto H., Shimada Y., Terasawa K., Phytother Res., 16, 373-376 (2002) .

19) Okawa M., Kinjo J., Nohara T., Ono M., Biol. Pharm. Bull., 24, 1202-1205 (2001).

20) Maeda K., Naganuma M., Fukuda M., Matsunaga J., Tomita Y., Pigment Cell Res., 9, 204-212 (1996).

21) Im S., Lee E.-S., Kim W., On W., Kim J., Lee M., Kang W. H., J. Korean Med. Sci., 17, 5864 (2002).

22） Ebanks J., Wickett R., Boissy R., Int. J. Mol. Sci., 10, 4066-4087 (2009).

23) Sakamoto S., Kudo H., Kawasaki T., Kuwa K., Kasahara N., Sassa S., Okamoto R., J. Ethnopharmacol., 23, 151-158 (1988).

24) North American Menopause Society, Menopause, 10, 113-132 (2003).

25) Smith D., Spaulding D., Glenn H., Fuller B., Exp. Cell Res., 15, 521-534 (2004). 